\title{
Research on English Situational Teaching in Primary Schools in China-Based on the Statistics and Analysis of CNKI Journals and Theses from 2014 to 2019
}

\author{
Xi-ping $\mathrm{Li}^{1}$ \\ ${ }^{1}$ Foreign Language College, Changsha Normal University, Changsha, China \\ Correspondence: Xi-ping Li, Foreign Language College, Changsha Normal University, Changsha City, Hunan \\ Province, 410100, China.
}

Received: April 2, 2020

Accepted: April 22, 2020

Online Published: April 23, 2020

doi: 10.5539/elt.v13n5p101

URL: https://doi.org/10.5539/elt.v13n5p101

\begin{abstract}
Situational Teaching plays a crucial role in English classroom teaching in Chinese Primary Schools; hence the relevant research prospers simultaneously. This study is devoted to reveal the research characteristic on English Situational Teaching in Primary Schools in the past 6 years. Result of contrastive analysis and survey of the essays published on CNKI Journals and Theses from year 2014 to 2019 reveals: 1) In terms of the whole field, it develops steadily in spite of lack of wide coverage and depth. 2) In regarding to the research content in whole, it is relatively disproportionate, identical and superficial with too much perceptual thinking and the micro aspect of specific application and promotion but far less scientific, empirical and experimental research. Moreover, there are too many nonstandard essays and few outstanding ones. 3) As to the research method, the distribution of the employment of the 3 methods is imbalance with too little use of the experimental and quantitative ones. Furthermore, the journal authors are unskilled in employment of multiple methods. 4) With respect to the research team, it is unstable, low productive and too centralized with primary school teachers.
\end{abstract}

Keywords: English situational teaching, primary school, research content, research team, research method

\section{Literature Review}

\subsection{Situational Teaching}

Initiated by American psychologist Dewey at the beginning of the 20th century, Situational Cognition Theory is based on behaviorist psychology and sums up learning as a process of stimulation-response-reinforcement. It posits that learning is an active, constructive process in which the learner constructs knowledge and meaning based upon their experiences and current/past knowledge (Wang, Q.Q. 2017). It emphasizes on the creation of a conducive learning environment where encourage the learners to construct their own perception of reality based on their experience and beliefs as well as dialogues with others. And it advocates that the learning activities should encompass the real world, worthwhile results and authentic experiences (Mynard, 2003, cited by Maryam Foroutan). Meanwhile it also suggests that teaching should be based on the learner's life experience, cognitive characteristic and teaching content, and that in the teaching process, teaching content and practical activities should be linked to students' real life and creation in the most familiar way(Wang, F. 2017, Qian, 2017).

Nowadays, modern foreign language education focuses on the process of language learning and stresses triggering the learner's desire to explore and mobilize their initiative and participation by an open learning environment with harmony, relaxed atmosphere. And it is well-known that the Situational Language Teaching Approach is widely used in the English teaching internationally. Consequently, many researchers are constantly on the move to discover new ways and methods to teach English language more effectively by applying Situational Teaching, many of which focus on the practice in primary schools (Gao, 2014).

\subsection{Research on ESTPS in China}

The Chinese Elementary English Curriculum Standards emphasizes that English teaching in primary schools should be based on the learning interest, life experience and level of awareness. Therefore, it advocates a learning style of experiencing, practicing, participating and cooperating to make the language learning process become a process of forming positive emotional attitude, active thinking and practicing for students. The 
characteristics of situational teaching, such as visual images, teaching in fun, paying attention to the independent construction of students' cognition, are in line with the cognitive needs of English subjects and pupils, which is helpful to stimulate students' learning motivation and interest, as well as the development of creativity and imagination (Wu, 2014).

As one of the most popular teaching approaches, the application of Situational Teaching has become increasingly widespread, and relevant research emerges rapidly in the mainland of China. Based on comprehensive analysis, the following 3 categories attract more highlights: 1) from the perspective of connation and characteristic, Gao (2014) summarizes the definition and the development history of Situational Teaching in English in China and points out "Four Focuses and Four Ignorance" as its defects. Lv Wenjing (2008) believes that context-based English teaching has the commonality of general teaching, such as completeness, conciseness, openness and operability, etc. It also has its own thinking personality characteristics such as "providing rich and meaningful situations with real activities and tasks; creating a learner-centered learning environment; and the teacher's 'bracket' role". And Qian (2017) believes that situational teaching in English in primary schools is based on a theme as a main line throughout the classroom teaching process. The whole classroom teaching process is promoted around the main theme; at the same time, situational teaching depends on the teaching medium. While Wang (2017) summarizes the definition and feature of the English Situational Teaching in Primary Schools (ESTPS) and points out that it should be implemented on the basis on students' life experience, cognitive characteristics and teaching content. 2) From the perspective of teaching principle and strategy, Tian Xiang (2013) points out that the creation of the situation must first be targeted and hierarchical; secondly, the curriculum resources should be comprehensively applied; finally, the creation of the situation must be authentic and can create a good environment of learning language for students. While Deng Jia-jia (2015) recommends that the essence of ESTPS lies in the teacher's competence of creation of targeted and hierarchical teaching situations based on the teaching materials and the learner's psychological characteristics, which can stimulate the students to acquire knowledge, cultivate abilities, develop abilities, and then achieve the desired goals. 3) Many scholars explore from the perspective of "problem and countermeasure" by means of investigation and survey. Namely, Zhang (2016) summarizes the problems existing in the application of Situational Teaching in oral English teaching in primary schools based on investigation and analysis, and hence puts forward some strategies to improve its teaching quality. $\mathrm{Hu}$ (2016) proposes that the main problems of ESTPS are as follows: firstly, many created contextual situations cannot fully attract the attention of students for the lack of integrated or authentic environment as well as scientific design. Secondly, there is rare real effective teacher-student interaction in the teaching process. While Shi Zhen zhen (2016) points out that the implementation effect of ESTPS is not satisfied due to the following factors: simple situational material based on the teaching content, the created situation lack of life reality and innovation consciousness, and heavy teaching task etc. Meanwhile Shi (2016) also proposes some corresponding countermeasures such as emphasizing the learner's subjective status, comprehensive use of teaching evaluation; the combined use of a variety of means and methods to create teaching situations; adjustment of the situational organization model as well as enriching the Situational Teaching materials, etc.

In order to investigate the current research status of ESTPS in the mainland of China, the author implements a survey and finds the relevant research is very rare: Firstly, the topic "research of English Situational Teaching in Primary Schools" is searched in CNKI (China National Knowledge Infrastructure) journal full-text database on Jan. 25, 2020, and there are 52 articles found. After the analysis of the research result in terms of content and correlation to the topic, none papers is closely relevant. This demonstrates that this topic attracts rare researchers' attention and therefore deserves explorations. Secondly, the topic "English Situational Teaching in Primary Schools" is searched in CNKI theses full-text database and there are 41 articles found. After the analysis of these articles in terms of content and correlation to the topic, none papers in whole is closely matched. But some of them (such as Gao, 2014; Wu, 2014; Wang, 2018, etc) contain some summarization of the current research status. Therefore, strictly speaking, the research review of ESTPS remains almost blank and deserves scientific analysis and research.

\section{Research Design}

\subsection{Research Question}

This research is designed to reveal the characteristic of the Chinese research of ESTPS in the past 6 years based on investigation of papers on CNKI Journals and theses from 2014 to 2019. The following questions are the goal of the research: 1) what is the characteristic of research on ESTPS in China in terms of the research content, research method and the research team? 2) What aspect should be improved in future based on the above analysis? 


\subsection{Research Object and Procedure}

Considering the authority and broad coverage, the object of this study is mainly to extract information of the research papers on ESTPS published from Jan.1, 2014-Dec.31, 2019 in CNKI Journals and Theses database.

Firstly, the researcher chooses all the journals and theses in CNKI as the object resource. Secondly, the topic "English Situational Teaching in Primary Schools" is searched in "CNKI journal and theses full-text database" in the above-mentioned period and gets 214 papers (see table 1). Thirdly, after the analysis of the research result in terms of content and correlation to the topic, 27 papers in conference, non-primary school and non-English are excluded out of the statistics, the final 187 articles left into the scope of research. Fourthly, after analysis of the object of these 187 papers, the author classifies them into 3 kinds: 34 thesis articles, forming the Thesis Database; 151 journal ones and 2 newspaper articles, forming the Journal Database.

Table 1. Statistics of initial distribution of statistical papers in terms of publishing resources

\begin{tabular}{|c|c|c|c|c|c|c|}
\hline \multirow{2}{*}{ Type } & \multicolumn{2}{|c|}{ Theses } & \multicolumn{2}{|c|}{ Journals } & \multirow{2}{*}{ Newspapers } & \multirow{2}{*}{ Total } \\
\hline & Doctoral & Master's & General & Core & & \\
\hline Number & 1 & 40 & 158 & 0 & 2 & 214 \\
\hline
\end{tabular}

Note: the classification of core journal is based on the classification of "2014 edition of Peking University's core journal directory"

\subsection{Research Method}

This research applies the method of "literature retrieval and statistical analysis". Firstly, the researcher determines the classification standard of the research of ESTPS from the aspects of content and method. After consulting with the division of research content by Wang (2004); Liu, Ling (2012); Yan, Cui (2011), Li (2014), the researcher classifies the research content into six aspects (see table 2). With reference to the classification of research methods in applied linguistics by Wen, Wang (2004); Guo (2009) and Li (2014), the researcher divides them into three categories (see table 2). Moreover, the difference between the quantitative and qualitative method is based on the priority of statistics or the text analysis. Secondly, the classification of these 187 papers is implemented according to the above standard in the aspect of quantity, research contents, methods and the research team. In addition, for the sake of the convenience of the statistics and comparison, the researcher classifies the papers according to the source of its main conclusion based since some papers involve in multiple types in terms of the research contents and methods. For example, as to an article making use of both qualitative and quantitative methods, if the main conclusions and points of view base on statistical data, it is classified as the quantitative method.

Table 2. Classification of research content and method of English Situational Teaching

\begin{tabular}{|c|c|c|}
\hline Object & Main types & Subtypes \\
\hline \multirow{6}{*}{$\begin{array}{l}\text { Research } \\
\text { content }\end{array}$} & $\begin{array}{l}\text { Non-teacher teaching } \\
\text { environment }\end{array}$ & $\begin{array}{l}\text { Learner`s internal factors, development and application of teaching } \\
\text { resources, development and application of instructional technology }\end{array}$ \\
\hline & $\begin{array}{l}\text { Teaching principle and } \\
\text { mode }\end{array}$ & Teaching principle, teaching mode \\
\hline & $\begin{array}{l}\text { Teaching approach and } \\
\text { strategy }\end{array}$ & Teaching approach, teaching strategy \\
\hline & Teaching evaluation & Test, correction, feedback, evaluation \\
\hline & $\begin{array}{l}\text { Research review and } \\
\text { teaching reflection }\end{array}$ & Research review, teaching reflection \\
\hline & $\begin{array}{l}\text { Research on certain } \\
\text { teaching content }\end{array}$ & Vocabulary, discourse, grammar, spoken English, reading, etc \\
\hline \multirow{3}{*}{$\begin{array}{l}\text { Research } \\
\text { method }\end{array}$} & Quantitative method & Questionnaire, empirical research \\
\hline & Qualitative method & $\begin{array}{c}\text { Observation, case/sample analysis, interview and participation } \\
\text { experience }\end{array}$ \\
\hline & Experimental method & \\
\hline
\end{tabular}




\section{Research Result and Analysis}

\subsection{Quantity}

Table 3. Statistics of distribution of statistical papers in terms of publishing resources

\begin{tabular}{ccccc}
\hline Type & Theses & Journals & Newspapers & Total \\
\hline 2014 & 6 & 24 & 1 & 31 \\
\hline 2015 & 3 & 23 & 0 & 26 \\
\hline 2016 & 10 & 31 & 0 & 41 \\
\hline 2017 & 6 & 25 & 1 & 32 \\
\hline 2018 & 3 & 23 & 0 & 26 \\
\hline 2019 & 6 & 25 & 0 & 31 \\
\hline Total & 34 & 151 & 2 & 187 \\
\hline
\end{tabular}

As Table 3 shows:

1) In total number, there are 187 papers published in the past 6 years, which demonstrates that ESTPS is a stable research topic and many researchers and front-line teachers try to reveal its characteristic in various aspects.

2) In annual total number of papers published on journals by year, it stays stable with a top in 2016, and the difference among other years is very slight and can be neglected. Likewise, the research peak in the Thesis Database also appears in 2016, and there is a slight difference in other years. All these evidences further confirm that ESTPS accouters for a stable proportion in the field of language teaching research and can be regarded as a prevalent teaching approach in these years.

3) When it comes to the classification of journals, there is not any core journal papers found, which indicates that the current research lacks of high quality achievements in depth.

4) In whole, the current research develops steadily with lack of wide depth.

\subsection{Research Content}

According to the relevant factors affiliating teaching, the researcher divides the research content into the following 6 aspects: "non-teacher teaching environment", "teaching principle and mode", "teaching approach and strategy", "teaching evaluation", "research review and teaching reflection" as well as "research on certain teaching content".

\subsubsection{Of Journal Papers}

Table 4. Statistics of distribution of statistical papers in terms of the research content in the Journal Database

\begin{tabular}{|c|c|c|c|c|c|c|c|c|c|}
\hline Research content & & 2014 & 2015 & 2016 & 2017 & 2018 & 2019 & Total & $\%$ \\
\hline \multirow{4}{*}{ Non-teacher teaching environment } & $\begin{array}{c}\text { Learner`s } \\
\text { internal } \\
\text { factors }\end{array}$ & 0 & 0 & 0 & 0 & 0 & 0 & 0 & 0 \\
\hline & $\begin{array}{c}\text { Development } \\
\text { and } \\
\text { application } \\
\text { of teaching } \\
\text { resource }\end{array}$ & 0 & 3 & 3 & 0 & 0 & 0 & 6 & 3.9 \\
\hline & $\begin{array}{c}\text { Development } \\
\text { and } \\
\text { application } \\
\text { of teaching } \\
\text { technology }\end{array}$ & 1 & 0 & 0 & 0 & 2 & 1 & 4 & 2.6 \\
\hline & Total & 1 & 3 & 3 & 0 & 2 & 1 & 10 & 6.5 \\
\hline
\end{tabular}




\begin{tabular}{|c|c|c|c|c|c|c|c|c|c|}
\hline \multirow{3}{*}{ Teaching principle and mode } & $\begin{array}{l}\text { Teaching } \\
\text { principle }\end{array}$ & 3 & 3 & 2 & 1 & 0 & 3 & 12 & 7.8 \\
\hline & $\begin{array}{l}\text { Teaching } \\
\text { mode }\end{array}$ & 2 & 0 & 1 & 0 & 1 & 0 & 4 & 2.6 \\
\hline & Total & 5 & 3 & 3 & 1 & 1 & 3 & 16 & 10.5 \\
\hline \multirow{3}{*}{ Teaching approach and strategy } & $\begin{array}{l}\text { Teaching } \\
\text { strategy }\end{array}$ & 14 & 8 & 16 & 20 & 13 & 16 & 87 & 56.8 \\
\hline & $\begin{array}{l}\text { Teaching } \\
\text { approach }\end{array}$ & 1 & 3 & 3 & 0 & 1 & 1 & 9 & 5.9 \\
\hline & Total & 15 & 11 & 19 & 20 & 14 & 17 & 96 & 62.7 \\
\hline \multirow{4}{*}{ Teaching evaluation } & Test & 0 & 0 & 0 & 0 & 0 & 0 & 0 & 0 \\
\hline & Feedback & 0 & 0 & 0 & 0 & 0 & 0 & 0 & 0 \\
\hline & Evaluation & 0 & 0 & 0 & 0 & 0 & 0 & 0 & 0 \\
\hline & Total & 0 & 0 & 0 & 0 & 0 & 0 & 0 & 0 \\
\hline \multirow{3}{*}{ Research review and teaching reflection } & $\begin{array}{l}\text { Research } \\
\text { review }\end{array}$ & 0 & 0 & 0 & 0 & 0 & 0 & 0 & 0 \\
\hline & $\begin{array}{l}\text { Teaching } \\
\text { reflection }\end{array}$ & 0 & 0 & 4 & 1 & 1 & 1 & 7 & 4.6 \\
\hline & Total & 0 & 0 & 4 & 1 & 1 & 1 & 7 & 4.6 \\
\hline \multirow{5}{*}{ Research on certain teaching content } & Discourse & 0 & 3 & 0 & 0 & 1 & 2 & 6 & 3.9 \\
\hline & Vocabulary & 3 & 3 & 2 & 1 & 1 & 0 & 10 & 6.5 \\
\hline & $\begin{array}{l}\text { Spoken } \\
\text { English }\end{array}$ & 1 & 0 & 0 & 2 & 2 & 1 & 6 & 3.9 \\
\hline & Else & 0 & 0 & 0 & 1 & 1 & 0 & 2 & 1.3 \\
\hline & Total & 4 & 6 & 2 & 4 & 5 & 3 & 25 & 16.3 \\
\hline Total & & 25 & 23 & 31 & 26 & 23 & 25 & 153 & \\
\hline
\end{tabular}

As table 4 shows:

1) The hotspot focuses on three aspects as "teaching approach and strategy (occupying 62.7\%)", "research on certain teaching content (occupying 16.3\%)" as well as "teaching principle and mode (occupying 10.5\%)". The first 4 guiding topics in turn are: the "teaching strategy (occupying 56.8\%), teaching principle (occupying 7.8\%), vocabulary (occupying 6.5\%)" as well as the "teaching approach (occupying 5.9\%)".

2) The blank spot is the "teaching evaluation" -without any papers found. Specific blank topics include the "learner's internal factors", "test", "feedback", "evaluation" and the "research review".

3) Other spots or topics are among average level regarding to the number of papers.

4) Combined with the text analysis, the researcher finds 2 more limitations in this database as follows: one is there are too many repetitive or highly identical research contents-not only in the topic but also in the title of the papers and even in the text of the discourse of various papers. According to statistics, there are 17 papers titled "discussion on the application of Situational Teaching in English teaching in Primary Schools" or similarly in the Journal Database, giving priority to the "importance/significance" or "strategy" or "method" as well as the "problem and countermeasure" of ESTPS, their viewpoints are highly identical to each other. This phenomenon indicates that the current research lacks of innovation, scientific manner and high competence. The other is the current research is relatively superficial because the overwhelming research content focuses on the description of certain strategy, method or experience of the practical application of ESTPS but more difficult and advanced aspects such as "teaching evaluation" barely remains untouched, which implies that the current research stays at a relatively simple and low stage and thus without high scientific value and vital significance.

5) In all, the current research content of the Journal Database is disproportionate in certain topics, superficial in depth and repetitive in both topics and viewpoints. 


\subsubsection{Of Thesis Papers}

Table 5. Statistics of distribution of statistical papers in terms of the research content in the Thesis Database

\begin{tabular}{|c|c|c|c|c|c|c|c|c|c|}
\hline Research content & & 2014 & 2015 & 2016 & 2017 & 2018 & 2019 & Total & $\%$ \\
\hline \multirow{4}{*}{ Non-teacher teaching environment } & $\begin{array}{c}\text { Learner`s } \\
\text { internal } \\
\text { factors }\end{array}$ & 0 & 0 & 0 & 0 & 0 & 0 & 0 & 0 \\
\hline & $\begin{array}{c}\text { Development } \\
\text { and } \\
\text { application } \\
\text { of teaching } \\
\text { resource }\end{array}$ & 0 & 0 & 0 & 0 & 0 & 0 & 0 & 0 \\
\hline & $\begin{array}{l}\text { Development } \\
\text { and } \\
\text { application } \\
\text { of teaching } \\
\text { technology }\end{array}$ & 0 & 0 & 0 & 0 & 0 & 0 & 0 & 0 \\
\hline & Total & 0 & 0 & 0 & 0 & 0 & 0 & 0 & 0 \\
\hline \multirow{3}{*}{ Teaching principle and mode } & $\begin{array}{l}\text { Teaching } \\
\text { principle }\end{array}$ & 4 & 1 & 1 & 0 & 0 & 0 & 6 & 17.6 \\
\hline & $\begin{array}{l}\text { Teaching } \\
\text { mode }\end{array}$ & 0 & 0 & 0 & 0 & 0 & 0 & 0 & 0 \\
\hline & Total & 4 & 1 & 1 & 0 & 0 & 0 & 6 & 17.6 \\
\hline \multirow{3}{*}{ Teaching approach and strategy } & $\begin{array}{l}\text { Teaching } \\
\text { strategy }\end{array}$ & 0 & 0 & 2 & 1 & 0 & 1 & 4 & 11.8 \\
\hline & $\begin{array}{l}\text { Teaching } \\
\text { approach }\end{array}$ & 0 & 0 & 0 & 0 & 1 & 0 & 1 & 2.9 \\
\hline & Total & 0 & 0 & 2 & 1 & 1 & 1 & 6 & 17.6 \\
\hline \multirow{4}{*}{ Teaching evaluation } & Test & 0 & 0 & 0 & 0 & 0 & 0 & 0 & 0 \\
\hline & Feedback & 0 & 0 & 0 & 0 & 0 & 0 & 0 & 0 \\
\hline & Evaluation & 0 & 0 & 0 & 0 & 0 & 0 & 0 & 0 \\
\hline & Total & 0 & 0 & 0 & 0 & 0 & 0 & 0 & 0 \\
\hline \multirow{3}{*}{ Research review and teaching reflection } & $\begin{array}{l}\text { Research } \\
\text { review }\end{array}$ & 0 & 0 & 0 & 0 & 0 & 0 & 0 & 0 \\
\hline & $\begin{array}{l}\text { Teaching } \\
\text { reflection }\end{array}$ & 1 & 1 & 4 & 4 & 2 & 2 & 14 & 41.2 \\
\hline & Total & 1 & 1 & 4 & 4 & 2 & 2 & 14 & 41.2 \\
\hline \multirow{5}{*}{ Research on certain teaching content } & Discourse & 0 & 0 & 0 & 0 & 0 & 0 & 0 & 0 \\
\hline & Vocabulary & 0 & 0 & 1 & 0 & 0 & 2 & 3 & 8.9 \\
\hline & $\begin{array}{l}\text { Spoken } \\
\text { English }\end{array}$ & 0 & 1 & 1 & 1 & 0 & 0 & 3 & 8.9 \\
\hline & Else & 1 & 0 & 1 & 0 & 0 & 1 & 3 & 8.9 \\
\hline & Total & 1 & 1 & 3 & 1 & 0 & 3 & 9 & 26.5 \\
\hline Total & & 6 & 3 & 10 & 6 & 3 & 6 & 34 & \\
\hline
\end{tabular}

As table 5 shows:

1) The research contends is relatively polarized and can be classified into two kinds: hotspots and blank spots.

2) The hotspot focuses on the following 4 aspects as "teaching reflection (occupying 41.2\%)", "research on 
certain teaching content(occupying 26.5\%)" as well as "teaching principle and mode (occupying 17.6\%)" and " teaching approach and strategy (occupying 17.6\%). The top 5 hot topics in turn are: "teaching reflection (occupying 40\%)", "teaching principle (occupying 17.1\%)", "teaching strategy (occupying 11.8\%)" and "vocabulary (occupying 8.9\%)" as well as "spoken English (occupying 8.9\%)".

3) The blank spot is left on 2 aspects: "non-teacher teaching environment" and "teaching evaluation" -without any such papers found. Specific blank topics not only cover all the sub-type of the above 2 aspects but also the following subtypes: "teaching mode", "research review" and "discourse".

4) Combined with the text analysis and compared to the Journal Database, its feature is more complicated, centralized with ignorance of the critical field. According to statistics, the overwhelming research topic lies in the systematical investigation, summarization and exploration of the current application-related issues of the ESTPS such as its current status, existing problem and countermeasure etc in various dimensions-better than the simple description of one's own experience. But they are too crowded in the general application other than in various districts, grades, language skills or types of teaching classes because 17 papers out of 34 are engaged in the same topic as "the investigation of the application of ESTPS" or likewise, and their research priorities have no distinct difference.

5) To sum up, the current research content in this Database is disproportionate in coverage, more advanced in depth and short of critical fields.

\subsubsection{In Whole}

Generally speaking, the research content is disproportionate in coverage, identical in both topics and viewpoints and superficial in depth. In addition, the perceptual thinking and the micro aspect of specific application and promotion account for the overweight proportion.

\subsection{Research Method}

1) All the researchers in the Journal Database apply the same method- qualitative method, mainly combination of "participation experience", "observation" and "case/sample analysis".

2) As figure 1 shows, methods employed by the Thesis authors are uneven- the quantitative one is extremely prominent, mainly "questionnaires" and "case/sample analysis", but most authors have not scientifically and meticulously analyzed the result of questionnaires because they seldom used the statistical analysis software SPSS and SAS to verify their conclusions.

3) Combine with the text analysis, the above 2 features further confirm with the previous finding that journal researchers lay almost all stresses on individual perceptual thinking such as observation, participation experience, which may lead to less scientific and rigorous conclusion. Furthermore, compared to other similar fields, the experimental and empirical research methods are far too less applied by thesis researchers, which may make their conclusions less convincing.

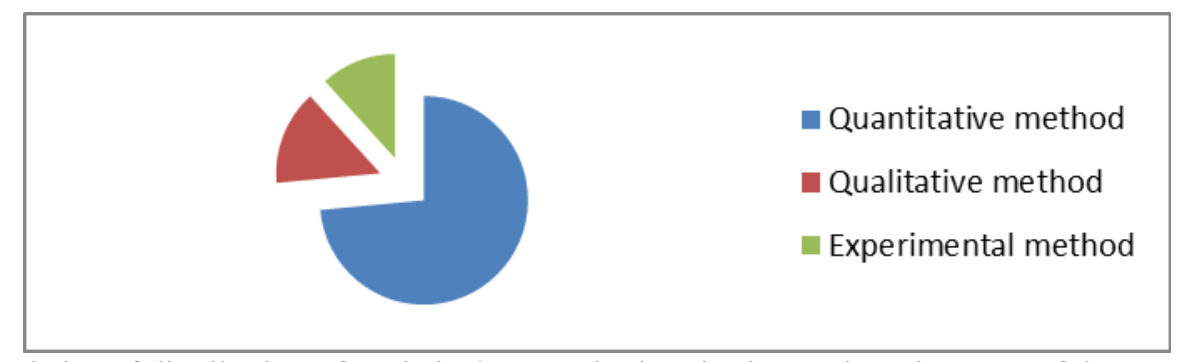

Figure 1. Statistics of distribution of statistical papers in the Thesis Database in terms of the research method

\subsection{Researchers}

1) All researchers of the Thesis Database definitely come from Universities or Colleges.

2) The research team of the Journal Database is mainly made up by primary school teachers - 132 out of 149 come from primary schools, only 14 from higher education institutions, 2 from middle schools and 1 from administrative institution of education.

3) The fixed research team has not formed and the number of active authors is very small. According to the analysis of the author's productivity, only 3 authors (Hu Wen-wen from Yunhe Teachers College, He ju from Siyang Yucai Bilingual School in Jiangsu Province and Wang Fang from Jiamusi 11th Primary School of Harbin Normal University, Heilongjiang Province) published 2 papers, the other authors each just published 1 papers in 
6 years. All these demonstrate that the research team is not so stable and productive.

4) To sum up, the current research team lacks stability, productivity and high-level members.

\subsection{Other Findings}

1) Many researchers especially primary school teachers are unskilled academic writers and need further training, which can be inferred from the following facts: a) that all journal essays are short in length- at an average about 600 words per piece, ranging from $800-300$ words. b) Many essays do not fit academic standard strictly- some of them have more than 2 focuses in a single piece; some titles are ambiguous and vague or imprecise. It is very hard to identify its theme only by means of reading its title; the situation of the Abstract follows suit. Some of them are meaningless or mismatch its body; consequently it is also hard to guess the outline or schedule of the essay via its Abstract.

2) Although many colorful Chinese- style practices such as the utility of various Chinese peculiar elements, namely, festivals, traditions and customs etc., have been roughly mentioned in these 2 databases, they are not systematically and scientifically evaluated, summarized, refined and tested, which results in the current achievements are less innovative and convincing.

\section{Conclusion}

\subsection{Conclusion}

In all, the research of ESTPS in China bears the following features:

1) As a whole, it develops steadily in spite of lack of wide coverage and depth.

2) The research content is relatively disproportionate, identical and superficial- some simpler topics such as "teaching approach and strategy" and "teaching reflections" attract far more attention and thus are crowded and highly repetitive; while more complicated and advanced topics such as "teaching evaluation" "learner's internal factors" and "research review" remain blank. In addition, the perceptual thinking and the micro aspect of specific application and promotion account for the overweight proportion; on the contrary, scientific, empirical and experimental research attract far less. Moreover, there are strictly speaking many nonstandard essays existing in the Journal Database

4) In terms of the research method, the distribution of the three methods is imbalance with too little use of experimental and quantitative ones. Furthermore, the journal authors' comprehensive competence of employment of multiple methods should be improved.

5 ) The research team is unstable, low productive and too centralized with primary school teachers.

\subsection{Limitation of the Research}

The reliability of the findings of this research is limited for the following reasons: Firstly, the source database is only limited to CNKI journal and thesis full-text database without international database in contrast, therefore, it is hard to identify the Chinese present status in the world without comparison. Secondly, the research method employed is relatively simple, mainly quantitative method and the text analysis, rather than corpus-based integrated methods, consequently, some findings may be less precise or convincing. Thirdly, the length of interception time span is a little short-only 6 years. Therefore the trend or change of research content can't be observed obviously. Fourthly, the classification of research content and method of a single article is not unique since it may involve multiple or complicated topics or method. Therefore, further investigation should base on larger variety of subjects and time span, more detailed analyses of research content. Moreover, qualitative and quantitative analysis rather than descriptive analysis based on the corpus of Chinese research can be taken into account as well.

\subsection{Suggestions for Future Research}

-To advocate innovative and original research.

-To encourage more explorations in those blank spots such as "learner's internal factors", "teaching test, feedback and evaluation".

-To attach more importance to experimental and empirical methods.

- To further enhance the level, stability and structure of the researchers.

\section{Acknowledgments}

This paper is supported by 2019 Social Science Achievement Project of Hunan Province in China under the project of "Research on the Model of English Education and Development of Supporting System to Preschool 
Children under Non-native Language Context" (Grant No. XSP19YBC147).

\section{References}

Deng jia-jia. (2015). The Research of the Situational Approach in primary English Language Teaching. A thesis submitted to Hunan Agricultural University, 3-13.

Gao, G. W. (2014). A Study on the Effective Implementation of Situational Teaching in Primary English Classroom Teaching. A thesis submitted to Liaoning Normal University, 5-6.

Guo, S. S. (2009). A review of China's second language writing research in the past 18 years (1991-2008). Shandong Foreign Language Teaching Journal, (5), 38-41.

Hu Wen-wen. (2016). Current English Situational Teaching Problems and Countermeasures in Primary Schools. A thesis submitted to Qufu Normal University, 7-10.

Li, X. P. (2014). Chinese Research on EFL Writing Teaching in the Past 5 Years: Based on the Statistics and Analysis of Language Authoritative Journals From 2009 to 2013. Studies in Literature and Language, 9(3), 77-85. https://doi.org/10.3968/5947

Liu, H. \& Ling, W. Y. (2012). Comparison and analysis between domestic and foreign studies on second-language writing. Journal of Yunnan Normal University, (3), 29 -40.

Maryam Foroutan \& Nooreen Noordin. (2012). Effect of Dialogue Journal Writing through the Use of Conventional Tools and E-mail on Writing Anxiety in the ESL Context. English Language Teaching, 5(1), 10-19. http://dx.doi.org/10.5539/elt.v5n1p10

Qian Lijuan. (2017). A Study on the Application of Situational Approach to Primary School English Teaching. A thesis submitted to Soochow University.

Shi Zhen-zhen. (2016). The Research on Problem and Countermeasures of English Situational Teaching in Primary School. A thesis submitted to Henan Normal University, 8-12.

Tian Xiang. (2017). A Study on Situational Teaching Strategies in Primary English Classroom. A thesis submitted to Tianjing Normal University, 11-14.

Wang Qian-qian. (2017). The Present Situation and Countermeasures of English Situational Teaching. A thesis submitted to Shanghai Normal University, 18-20.

Wang, F. (2017). Primary School English Study- the Application of Situational Teaching Strategy. A thesis submitted to Harbin Normal University, 10-13.

Wang, Q. N. (2018). The Investigation and Research of English Situational Teaching in Primary School. A thesis submitted to Yan` an University, 4-7.

Wang, W. Y. \& Wang, L. F. (2004). Second language writing research: Retrospect and prospect of ten years. Journal of Foreign Languages, (3), 52-59.

Wen, Q. F. \& Wang, L. F. (2004). Review and thinking of the research method of second language acquisition in the past 35 years. Journal of Foreign Languages, (4), 18-25.

Wu, P. L (2014). The Research of English Situational Teaching in Primary School. A thesis submitted to Hunan Normal University, 5-6.

Yan, X. R. \& Cui, S. S. (2011). The recent researches and prospects of L2 writing at home-based on the analysis of nine Kinds of key linguistic journals from 2006 to 2010. Journal of Beijing International Studies University, (2), 24 -30.

Zhang Ling-ling. (2016). Application of Situational Teaching Method in Oral English Teaching in Primary School. A thesis submitted to Hebei Normal University, 12-15. https://doi.org/10.17265/1539-8072/2015.08.002

\section{Copyrights}

Copyright for this article is retained by the author(s), with first publication rights granted to the journal.

This is an open-access article distributed under the terms and conditions of the Creative Commons Attribution license (http://creativecommons.org/licenses/by/4.0/). 